\title{
Thermodynamic and nutritional properties and drying kinetics of pequi (Caryocar brasiliense Cambess) mesocarp
}

\author{
Jéssica L. F. Souza ${ }^{1}$, Daniel E. C. Oliveira ${ }^{2}$, Geovana R. Plácido ${ }^{1}$, Mariana B. Egea ${ }^{1}$, Márcio Caliari ${ }^{3}$ \& \\ Marco A. P. da Silva ${ }^{1}$ \\ ${ }^{1}$ Instituto Federal Goiano. Rio Verde, GO, Brasil. E-mail: jessica.alimentos@gmail.com - ORCID: 0000-0001-8378-5437; geovana.placido@ifgoiano.edu.br - \\ ORCID: 0000-0002-3028-7191; mariana.egea@ifgoiano.edu.br - ORCID: 0000-0001-7589-2718; marco.antonio@ifgoiano.edu.br (Corresponding author) \\ - ORCID: 0000-0002-3875-1104 \\ ${ }^{2}$ Instituto Federal Goiano. Iporá, GO, Brasil. E-mail: oliveira.d.e.c@gmail.com - ORCID: 0000-0002-3824-994X \\ ${ }^{3}$ Universidade Federal de Goiás. Goiânia, GO, Brasil. E-mail: marcio.caliari@pq.cnpq.br - ORCID: 0000-0002-0877-8250
}

\begin{abstract}
The objectives of this study were to fit mathematical models to the experimental data of the drying of the pequi mesocarp, determine the effective diffusion coefficient, and to obtain activation energy and thermodynamic and nutritional properties in different drying conditions. The mesocarp of pequi fruits, with an initial moisture content of 5.05 (decimal, dry basis), was dried in a forced ventilation oven at temperatures of $40,50,60$ and $70^{\circ} \mathrm{C}$ until the final moisture content of $0.15 \pm 0.01$ (decimal, dry basis). The mathematical models were adjusted by non-linear regression analysis using the Gauss-Newton method, considering the magnitude of the coefficient of determination $\left(R^{2}\right)$, the mean relative error $(P)$ and the estimated mean error (SE). Among the models analyzed, the Midilli model presented the best fit. The effective diffusion coefficient increased with increase in temperature, and the activation energy on drying was $11.011 \mathrm{~kJ} \mathrm{~mol}^{-1}$. The enthalpy decreased with an increase in the drying temperature, while the entropy and Gibbs free energy increased with the drying temperature. The product obtained from drying has low lipid and high carbohydrate concentration, while temperatures above $70^{\circ} \mathrm{C}$ could cause denaturation and/or protein complexation. The temperature of $60^{\circ} \mathrm{C}$ is most suitable to obtain flour of pequi mesocarp, due to the shorter processing time while maintaining the nutritional quality.
\end{abstract}

Key words: mathematical modeling, activation energy, Midilli model, by-product utilization

\section{Propriedades termodinâmicas, nutricionais e cinética de secagem de mesocarpo de pequi (Caryocar brasiliense Cambess)}

RESUMO: Objetivou-se ajustar modelos matemáticos aos dados experimentais da secagem do mesocarpo externo do pequi, determinar o coeficiente de difusão efetivo, e obter a energia de ativação e as propriedades termodinâmicas e nutricionais em diferentes condições de secagem. O mesocarpo dos frutos de pequi com teor de água inicial de 5,05 (base seca, decimal), foi submetido à secagem em estufa de ventilação forçada nas temperaturas de $40,50,60$ e $70^{\circ} \mathrm{C}$ até atingir o teor de água final de $0,15 \pm 0,01$ (base seca, decimal). Os modelos matemáticos foram ajustados por análise de regressão não linear pelo método Gauss-Newton, sendo considerada a magnitude do coeficiente de determinação $\left(\mathrm{R}^{2}\right)$, do erro médio relativo $(\mathrm{P})$ e do erro médio estimado (SE). Entre os modelos analisados, Midilli apresentou o melhor ajuste aos resultados. O coeficiente de difusão efetivo aumentou com a elevação da temperatura, e a energia de ativação para a difusão líquida na secagem foi de $11,011 \mathrm{~kJ} \mathrm{~mol}^{-1}$. A entalpia de ativação diminuiu com o aumento da temperatura de secagem, enquanto a entropia e a energia livre de Gibbs de ativação aumentaram com o acréscimo da temperatura de secagem. O produto obtido a partir da secagem possui baixo teor lipídico e elevado teor de carboidratos, enquanto que temperaturas a partir de $70^{\circ} \mathrm{C}$ podem causar desnaturação e/ou complexação proteica. A temperatura de $60^{\circ} \mathrm{C}$ é mais indicada para obtenção do farináceo do mesocarpo do pequi, devido ao menor tempo de processamento com manutenção da qualidade nutricional.

Palavras-chave: modelagem matemática, energia de ativação, modelo de Midilli, aproveitamento de subproduto

Ref. 197274 - Received 01 May, 2018 • Accepted 16 Jul, 2019• Published 31 Jul, 2019 


\section{INTRODUCTION}

The Cerrado biome is the second largest vegetal formation in Brazil, which originally covered $21 \%$ of the national territory, and contains the richest flora among the world's savannas, with a high level of endemism. However, in recent years, more than half of the 2 million $\mathrm{km}^{2}$ area has been converted into planted pastures and arable land (Klink \& Machado, 2005).

The pequi (Caryocar brasiliense Cambess) stands out as a native fruit of high socioeconomic importance and nutritional value (Vera et al., 2005). The commercial use of pequi pulp provides a large amount of by-product that is constituted of the epicarp and external mesocarp; therefore, its use is of interest in research.

A conservation technique that has been used for the utilization of by-products for meal production is drying, because it reduces water activity and decreases microbial growth and the speed of enzymatic and oxidative degradation reactions. Further, it reduces the volume, and it facilitates transport and storage (Park et al., 2001). The drying process can also modify the nutritional value, because many nutrients are sensitive to thermal processing and may degrade (Bazyma et al., 2006). In addition, because it is a complex phenomenon, the drying process has been studied with respect to its influence on the final product quality. It has been described using theoretical models that focus on the internal mechanisms of energy and water mass transportation, for instance, the hydrodynamic flow and the liquid, capillary, superficial, vapor and thermal diffusions (Brooker et al., 1992).

Based on the above discussion, the objectives of this study were to fit mathematical models to the experimental data of the drying of the pequi mesocarp, determine the effective diffusion coefficient, and to obtain activation energy and thermodynamic and nutritional properties in different drying conditions.

\section{Material ANd Methods}

The residues of pequi fruits (Caryocar brasiliense Cambess), including the peel (drupe except putamen), were obtained from a street market in the municipality of Rio Verde, GO, Brazil, from the 2015 harvest in Northern Minas Gerais, Brazil. The fruits were selected based on their satisfactory visual aspect, without mechanical damage and no apparent microbiological contamination.

Residues were manually peeled, and the epicarp and external mesocarp were separated. The mesocarp was sanitized ( $\mathrm{NaClO} 0.015 \%$ for $15 \mathrm{~min}$ ), bleached ( $0.25 \% \mathrm{NaHSO}_{3}$ for $2 \mathrm{~min}$ ), rinsed in running water, and fractionated $(1.65 \times 1.66 \times 0.77 \mathrm{~cm}$; length $\times$ width $\times$ thickness). For drying, the mesocarps were distributed in three trays with a nylon mesh, with a layer thickness of approximately $1 \mathrm{~cm}$, allowing air flow, and placed in a forced air circulation oven (Marconi ${ }^{\circledR} / \mathrm{MA}-035$ ) at 40,50, 60 and $70{ }^{\circ} \mathrm{C}$. The relative humidity was monitored during drying by a digital thermo-hygrometer as 19.8, 11.8, 7.3 and $4.7 \%$, respectively, to $40,50,60$ and $70{ }^{\circ} \mathrm{C}$; the air speed was monitored using an anemometer at $2.81 \pm 0.34 \mathrm{~m} \mathrm{~s}^{-1}$. The trays were successively weighed until $0.15 \pm 0.01$ final moisture content (dry basis).
The pequi mesocarp had a 5.05 initial moisture content (dry basis), determined in an oven at $105 \pm 1^{\circ} \mathrm{C}$ over $24 \mathrm{~h}$ with nine replicates (AOAC, 2012) of approximately $15 \mathrm{~g}$.

For the determination of moisture content ratios in pequi mesocarp during the drying process, the following equation was used.

$$
R X=\frac{X-X_{e}}{X_{i}-X_{e}}
$$

where:

RX - moisture content ratio, dimensionless;

$\mathrm{X}$ - product moisture content, decimal, dry basis (d.b.);

$\mathrm{X}_{\mathrm{i}}$ - initial product moisture content, decimal, d.b.; and,

$\mathrm{X}_{\mathrm{e}}$ - equilibrium moisture content of product, decimal, d.b.

The experimental data of the pequi mesocarp drying process were adjusted by empirical mathematical models (Table 1).

Table 1. Mathematical models used to predict the drying process

\begin{tabular}{lll}
\hline \multicolumn{1}{c}{ Mathematical models } & \multicolumn{1}{c}{ Model } & Eqs. \\
$\mathrm{RX}=1+\mathrm{a} \mathrm{t}+\mathrm{b} \mathrm{t}^{2}$ & Wang and Singh & $(2)$ \\
$\mathrm{RX}=\mathrm{a} \exp (-\mathrm{k} \mathrm{t})+(1-\mathrm{a}) \exp \left(-\mathrm{k}_{1} \mathrm{t}\right)$ & Verma & $(3)$ \\
$\mathrm{RX}=\exp \left(\left(-\mathrm{a}-\left(\mathrm{a}^{2}+4 \mathrm{~b} \mathrm{t}\right)^{2}\right) / 2 \mathrm{~b}\right)$ & Thompson & $(4)$ \\
$\mathrm{RX}=\exp \left(-\mathrm{k} \mathrm{t}^{\mathrm{n}}\right)$ & Page & $(5)$ \\
$\mathrm{RX}=\exp (-\mathrm{kt})$ & Newton & $(6)$ \\
$\mathrm{RX}=\mathrm{a} \exp \left(-\mathrm{k} \mathrm{t} \mathrm{t}^{\mathrm{n}}\right)+\mathrm{bt}$ & Midilli & $(7)$ \\
$\mathrm{RX}=\mathrm{a} \exp (-\mathrm{k} \mathrm{t})+\mathrm{c}$ & Logarithmic & $(8)$ \\
$\mathrm{RX}=\mathrm{a} \exp (-\mathrm{k} \mathrm{t})$ & Henderson and Pabis \\
$\mathrm{RX}=\mathrm{a} \exp (-\mathrm{k} \mathrm{t})+(1-\mathrm{a}) \exp (-\mathrm{k} \mathrm{a} \mathrm{t})$ & Two terms exponential \\
$\mathrm{RX}=\mathrm{a} \exp \left(-\mathrm{k}_{0} \mathrm{t}\right)+\mathrm{b} \exp \left(-\mathrm{k}_{1} \mathrm{t}\right)$ & Two terms & $(10)$ \\
$\mathrm{RX}=\mathrm{a} \exp (-\mathrm{k} \mathrm{t})+(1-\mathrm{a}) \exp (-\mathrm{k} \mathrm{b} \mathrm{t})$ & Approximation of diffusion & $(12)$ \\
\hline $\mathrm{t}-$ Drying time $(\mathrm{hs}) ; \mathrm{k}, \mathrm{k}_{\mathrm{o}}, \mathrm{k}_{1}-\operatorname{Drying}$ constants $\left(\mathrm{h}^{-1}\right) ; \mathrm{a}, \mathrm{b}, \mathrm{c}, \mathrm{n}$ - Coefficients of the models
\end{tabular}

The mathematical models were adjusted by non-linear regression analysis using the Gauss-Newton method. The models were selected by considering the magnitude of the coefficient of determination $\left(\mathrm{R}^{2}\right)$, the mean relative error $(\mathrm{P})$, and the mean estimated error (SE) determined by Eqs. 13 and 14 .

$$
\begin{gathered}
\mathrm{P}=\frac{100}{\mathrm{~N}} \sum \frac{|\mathrm{Y}-\hat{\mathrm{Y}}|}{\mathrm{Y}} \\
\mathrm{SE}=\sqrt{\frac{\sum(\mathrm{Y}-\hat{\mathrm{Y}})^{2}}{\mathrm{RDF}}}
\end{gathered}
$$

where:

$\mathrm{P} \quad$ - mean relative error, \%;

$\mathrm{N}$ - number of experimental observations;

$\mathrm{Y}$ - experimental value;

$\hat{Y} \quad$ - value estimated by the model;

SE - mean estimated error; and,

$\mathrm{RDF}$ - residue degrees of freedom.

The effective diffusion coefficient for different drying conditions was determined based on the liquid diffusion 
theory, according to Fick's law, using the analytical solution for the geometric shape of an infinite cylinder with an approximation of eight terms (Eq. 15):

$$
\mathrm{RX}=\frac{\mathrm{X}-\mathrm{X}_{\mathrm{e}}}{\mathrm{X}_{\mathrm{i}}-\mathrm{X}_{\mathrm{e}}}=\sum_{\mathrm{n}=1}^{\infty} \frac{4}{\lambda_{\mathrm{n}}^{2}} \exp \left[-\frac{\lambda_{\mathrm{n}}^{2} \mathrm{Dt}}{4}\left(\frac{2}{\mathrm{r}}\right)^{2}\right]
$$

where:

$\lambda_{\mathrm{n}} \quad$ - roots of zero-order Bessel equation;

$\mathrm{n}$ - number of terms;

D - effective diffusion coefficient, $\mathrm{m}^{2} \mathrm{~s}^{-1}$;

t - drying time, s; and,

$\mathrm{r} \quad$ - equivalent radius, $\mathrm{m}$.

The equivalent radius ( $r$ ) of a fractioned pequi mesocarp was determined using Eq. 16.

$$
r=\sqrt[3]{\frac{3 V}{4 \pi}}
$$

where:

$\mathrm{V}$ - volume, $\mathrm{m}^{3}$.

The volume was obtained by measuring the three main characteristic dimensions (length, width and thickness) of fifteen pieces of residue at the end of the drying process, using a $0.01-\mathrm{mm}$-resolution digital caliper, according to Eq. 17.

$$
\mathrm{V}=\frac{\pi \mathrm{ABC}}{6}
$$

where:

$$
\begin{array}{ll}
\text { A } & \text { - length, m; } \\
\text { B } & \text { - width, m; and, } \\
\text { C } & \text { - thickness, m. }
\end{array}
$$

The relationship between the effective diffusion coefficient and the temperature of the drying air was described by Eq. 18, known as the Arrhenius Equation.

$$
\mathrm{D}=\mathrm{D}_{0} \exp \left(\frac{-\mathrm{E}_{\mathrm{a}}}{\mathrm{RT}_{\mathrm{ab}}}\right)
$$

where:

D - effective diffusion coefficient, $\mathrm{m}^{2} \mathrm{~s}^{-1}$;

$\mathrm{D}_{\mathrm{o}} \quad$ - pré-exponential factor, $\mathrm{m}^{2} \mathrm{~s}^{-1}$;

$\mathrm{E}_{\mathrm{a}} \quad$ - energy of activation, $\mathrm{kJ} \mathrm{mol}^{-1}$;

$\mathrm{R}$ - universal gas constant, $8.134 \mathrm{~kJ} \mathrm{kmol}^{-1} \mathrm{~K}^{-1}$; and,

$\mathrm{T}_{\mathrm{ab}}$ - absolute temperature, $\mathrm{K}$.

The thermodynamic properties of the drying process of pequi mesocarp were obtained by the method described by Jideani \& Mpotokwana (2009):

$$
\Delta \mathrm{H}=\mathrm{E}_{\mathrm{a}}-\mathrm{RT}_{\mathrm{ab}}
$$

$$
\begin{gathered}
\Delta S=R\left(\ln \mathrm{A}-\ln \frac{\mathrm{k}_{\mathrm{B}}}{\mathrm{h}_{\mathrm{p}}}-\ln \mathrm{T}_{\mathrm{ab}}\right) \\
\Delta \mathrm{G}=\Delta \mathrm{H}-\mathrm{T}_{\mathrm{ab}} \Delta \mathrm{S}
\end{gathered}
$$

where:

$\Delta \mathrm{H}$ - activation enthalpy, $\mathrm{J} \mathrm{mol}^{-1}$;

$\Delta S$ - activation entropy, $\mathrm{J} \mathrm{mol}^{-1}$;

$\Delta \mathrm{G}$ - Gibbs free activation energy, $\mathrm{J} \mathrm{mol}^{-1}$;

$\mathrm{k}_{\mathrm{B}} \quad$ - Boltzmann constant, $1.38 \times 10^{-23} \mathrm{~J} \mathrm{~K}^{-1}$; and,

$\mathrm{h}_{\mathrm{p}} \quad$ - Planck constant, $6.626 \times 10^{-34} \mathrm{~J} \mathrm{~s}^{-1}$.

The centesimal composition was determined by official methods (AOAC, 2012): moisture content (Method 925.09), ashes (Method 923.03), crude protein (Method 920.87) using the 5.75 conversion factor, and ethereal extract (Method 925.38). The total carbohydrate content was calculated by the difference method. The caloric values were calculated by the Atwater conversion factors (Merril \& Watt, 1973) based on the centesimal composition from the sum of the protein contents $\times 4$, lipids $\times 9$, and carbohydrates $\times 4$ (Horwitz \& Latimer, 2005). All analyses were performed with nine repetitions in a completely randomized design. The data were submitted to analysis of variance and regression.

\section{Results AND Discussion}

Table 2 presents the values of the coefficient of determination $\left(\mathrm{R}^{2}\right)$, mean relative error $(\mathrm{P})$, and mean estimated error $(\mathrm{SE})$ of the 11 models adjusted during the pequi mesocarp drying for meal production, at different temperatures.

It was observed that the determination coefficients $\left(\mathrm{R}^{2}\right)$ of Wang and Singh (2), Page (5), Midilli (7), logarithm (8) and approximation of diffusion (12) models, had values above 95\% for all tested drying temperatures, which, according to Kashaninejad et al. (2007), may suggest an adequate representation of the experimental data. However, a good evaluation of non-linear models requires the use of other statistical indexes, such as the mean error and estimated error (Madamba et al., 2003).

Analyzing the values of the mean relative error $(\mathrm{P})$, it was observed that only the Midilli model (7) presented values below $10 \%$ for all tested conditions, indicating that this model is the most adequate for representing the drying phenomenon of pequi mesocarp, according to Mohapatra \& Rao (2005). On the other hand, the model Page (5), for the temperatures of 60 and $70{ }^{\circ} \mathrm{C}$, and the model Logarithmic (8), for temperature of $40{ }^{\circ} \mathrm{C}$, also presented $\mathrm{P}$ values below $10 \%$. Silva et al. (2014) modeled the drying of pequi pulp at 40,50 and $60^{\circ} \mathrm{C}$ and also concluded that the Midilli model satisfactorily represented this process. This same model was also efficiently adjusted by Sousa et al. (2017) in drying the pequi pulp at temperatures of $50,60,70$ and $80^{\circ} \mathrm{C}$.

Figure 1 shows the moisture content ratio of the product (RX, Figure 1A), the values of the effective diffusion coefficient (Figure 1B) and the dependence of the effective diffusion coefficient, represented by the Arrhenius expression 
Table 2. Coefficient of determination $\left(\mathrm{R}^{2}, \%\right)$, mean relative error $(\mathrm{P}, \%)$, and mean estimated error (SE) for pequi mesocarp drying at $40,50,60$ and $70^{\circ} \mathrm{C}$

\begin{tabular}{|c|c|c|c|c|c|c|c|c|c|c|c|c|}
\hline \multirow{2}{*}{ Equation } & \multicolumn{3}{|c|}{$40^{\circ} \mathrm{C}$} & \multicolumn{3}{|c|}{$50^{\circ} \mathrm{C}$} & \multicolumn{3}{|c|}{$60^{\circ} \mathrm{C}$} & \multicolumn{3}{|c|}{$70^{\circ} \mathrm{C}$} \\
\hline & $\mathbf{R}^{2}(\%)$ & $\bar{P}$ & SE & $\mathbf{R}^{2}(\%)$ & $\bar{P}$ & SE & $\mathbf{R}^{2}(\%)$ & $\bar{P}$ & SE & $\mathbf{R}^{2}(\%)$ & $\bar{P}$ & SE \\
\hline 2 & 99.27 & 22.42 & 0.03 & 98.85 & 20.93 & 0.04 & 97.81 & 37.96 & 0.05 & 97.88 & 23.76 & 0.05 \\
\hline 3 & 87.07 & 89.14 & 0.12 & 98.77 & 20.63 & 0.04 & 97.79 & 37.11 & 0.05 & 79.69 & 74.91 & 0.16 \\
\hline 4 & 87.06 & 88.67 & 0.12 & 87.27 & 69.73 & 0.12 & 87.65 & 91.76 & 0.13 & 79.69 & 74.67 & 0.16 \\
\hline 5 & 99.39 & 20.16 & 0.03 & 99.62 & 11.20 & 0.02 & 99.86 & 8.24 & 0.01 & 99.70 & 5.38 & 0.02 \\
\hline 6 & 87.07 & 88.67 & 0.12 & 87.27 & 69.74 & 0.12 & 87.66 & 91.80 & 0.12 & 79.69 & 74.69 & 0.15 \\
\hline 7 & 99.95 & 3.69 & 0.01 & 99.95 & 3.00 & 0.01 & 99.95 & 2.75 & 0.01 & 99.79 & 4.06 & 0.02 \\
\hline 8 & 99.07 & 8.74 & 0.03 & 99.01 & 12.31 & 0.03 & 98.50 & 29.82 & 0.04 & 96.58 & 15.06 & 0.06 \\
\hline 9 & 91.07 & 74.61 & 0.10 & 91.33 & 57.64 & 0.10 & 91.86 & 74.45 & 0.10 & 86.02 & 61.91 & 0.13 \\
\hline 10 & 98.98 & 23.34 & 0.03 & 87.27 & 69.73 & 0.12 & 87.66 & 91.79 & 0.13 & 79.69 & 74.69 & 0.16 \\
\hline 11 & 99.43 & 18.32 & 0.03 & 91.33 & 57.64 & 0.10 & 91.86 & 74.46 & 0.11 & 86.02 & 61.91 & 0.14 \\
\hline 12 & 99.18 & 22.48 & 0.03 & 97.96 & 30.08 & 0.05 & 98.44 & 34.84 & 0.05 & 96.21 & 33.13 & 0.07 \\
\hline
\end{tabular}
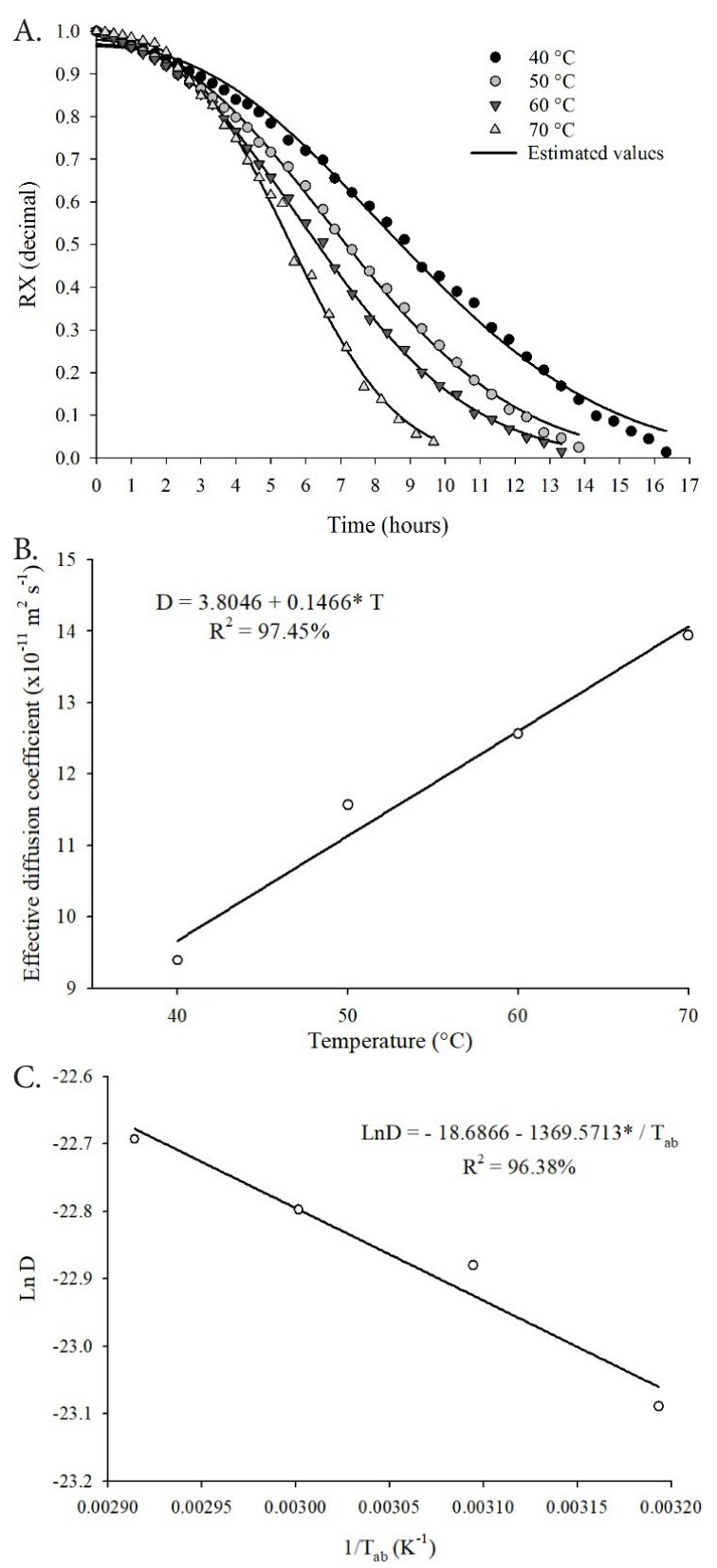

Significant at $\mathrm{p} \leq 0.05$ by the $\mathrm{F}$ test

Figure 1. (A) Moisture content ratio (RX), with experimental values and estimated values by the Midilli model, at 40, 50, 60 and $70^{\circ} \mathrm{C}$; (B) Effective diffusion coefficient - D as function of temperatures; and (C) Arrhenius representation for the effective diffusion coefficient - D, as a function of the inverse of pequi mesocarp drying air temperature (Tab)
(Figure 1C), for the tested drying conditions. There was a linear increase with temperature of $3.23 \times 10^{-11}, 3.71 \times 10^{-11}, 4.17 \times 10^{-11}$, and $4.63 \times 10^{-11} \mathrm{~m}^{2} \mathrm{~s}^{-1}$ for $40,50,60$ and $70{ }^{\circ} \mathrm{C}$ temperatures, respectively (Figure $1 \mathrm{~B}$ ).

The curves of pequi mesocarp values of moisture content ratio (RX) over time estimated by the Midilli model (Figure 1A) satisfactorily fit the experimental values.

Table 3 lists the values of coefficients a, $k, n$, and b of the Midilli model adjusted to the experimental data of pequi mesocarp drying at different temperatures.

The times required to reach $0.15 \pm 0.01$ (decimal, d.b.) moisture content ratio were $16.83,13.83,13.53$, and $9.21 \mathrm{~h}$ for 40, 50, 60 and $70^{\circ} \mathrm{C}$, respectively, (Figure 1A). As expected, the temperature increase resulted in a lower drying time for the pequi mesocarp. This decrease is related to the increase in internal partial vapor pressure provided by higher temperatures, which increase the difference between the vapor pressure of the drying air and the product and removes the water more easily and quickly (Kumar et al., 2014).

The coefficient $\mathrm{n}$ increased with an increase in the drying temperature; the other coefficients $\mathrm{a}, \mathrm{k}$, and $\mathrm{b}$ did not exhibit a clear trend as a function of temperature. The variations in coefficients $\mathrm{a}, \mathrm{n}$, and $\mathrm{b}$ are more related to mathematical adjustments than to a drying phenomenon, unlike coefficient $\mathrm{k}$. This is because the Midilli model is a semi-empirical model (Midilli et al., 2002).

The effective diffusion coefficient is directly influenced by an increase in the temperature, because this change modifies the water removal from the product. This result was also reported by Silva et al. (2014) and Sousa et al. (2017). Madamba et al. (2003) highlighted that the effective diffusion coefficients are of the order of $10^{-11}$ to $10^{-9} \mathrm{~m}^{2} \mathrm{~s}^{-1}$ for food products. The values found for pequi mesocarp were lower (around $10^{-11}$ ) compared with the work of Sousa et al. (2017) at 50-80 ${ }^{\circ} \mathrm{C}$ temperatures (of the order of $10^{-8}$ ), and higher than previously reported by Silva et al. (2014) from $10^{-14}$ to $10^{-15} \mathrm{~m}^{2} \mathrm{~s}^{-1}$ for

Table 3. Coefficients of the Midilli model adjusted to pequi mesocarp drying at $40,50,60$ and $70{ }^{\circ} \mathrm{C}$

\begin{tabular}{|c|c|c|c|c|}
\hline \multirow{2}{*}{ Coefficients } & \multicolumn{4}{|c|}{ Drying temperature ( ${ }^{\circ} \mathrm{C}$ ) } \\
\hline & 40 & 50 & 60 & 70 \\
\hline$a$ & $0.9877^{* *}$ & $0.9839^{* *}$ & $0.9837^{* *}$ & $0.9959^{* *}$ \\
\hline k & $0.0067^{\star *}$ & $0.0105^{\star *}$ & $0.0131^{* \star}$ & $0.0067^{* *}$ \\
\hline $\mathrm{n}$ & $1.9781^{\star \star}$ & $2.0237^{\star \star}$ & $2.1092^{\star \star}$ & $2.6338^{\star \star}$ \\
\hline$b$ & $-0.0107^{\star *}$ & $-0.0073^{* *}$ & $-0.0019^{* *}$ & $-0.0052^{*}$ \\
\hline
\end{tabular}

- Significant at $p \leq 0.05$ and $p \leq 0.01$ by the test 
temperatures between $40-60{ }^{\circ} \mathrm{C}$ for pequi pulp. The different temperatures used may have contributed to this difference in effective diffusion coefficient values.

Differences in diffusivity may be caused by the chemical composition of the products, such as lipid content, initial moisture content and primarily, size, geometric format and the structure of each material. Physical and chemical properties depend on the composition and play an important role in the water migration rate from the inside to the surface of the product, owing to greater or lesser affinity, as well as the structural nature of the material (Khan et al., 2016).

The activation energy for the liquid diffusion of pequi mesocarp was $11.01 \mathrm{~kJ} \mathrm{~mol}^{-1}$ for all studied temperatures. This is greater than that demonstrated by Silva et al. (2014) for pequi pulp $\left(7.69 \mathrm{~kJ} \mathrm{~mol}^{-1}\right)$. The activation energy can be defined as the energy that must be overcome to allow the migration of water molecules from the interior of the product to the exterior (Strumillo \& Kudra, 1986).

In the drying processes, the lower the activation energy the greater the water diffusivity of the product (Kayacier \& Singh, 2004). This can be proved by comparing the results obtained by this study and the results reported for pequi pulp by Silva et al. (2014). These values reflect the porosity structural characteristics and composition of the biological material under study. The high initial moisture content of pequi mesocarp influences the improved ease of water transport, given the concentration gradient.

In Figure 2 the enthalpy, entropy and free Gibbs energy values for the different drying conditions are shown. With the increase in drying temperature, the enthalpy and the entropy decrease, while free Gibbs energy increases.

Enthalpy is related to the energy required to remove the water attached to the product during the drying process; therefore, enthalpy decreases with an increase in the drying temperatures (Oliveira et al., 2010). A high enthalpy value at lower temperatures means that a greater amount of energy is required to dry the pequi mesocarp.

Entropy is a thermodynamic property that can be associated with the degree of disorder between the water and the product (Goneli et al., 2010). The entropy increased (in modulus) with the increase in drying air temperature, an alteration attributed to the reduction of the temperature that decreases the free energy by the excitation of water molecules in the product. This trend was similar to the drying of green Vigna subterranea (L.) seed (Jideani \& Mpotokwana, 2009). The negative entropy values can be due to the occurrence of chemical adsorption and/or structural changes in the adsorber (Moreira et al., 2008).

The free Gibbs energy is related to the work required to make the sorption sites available (Nkolo Mezee et al., 2008). It was observed that the free Gibbs energy investigated in this study was positive and increased with the drying temperature. A positive value for the free Gibbs energy indicates an endogenous reaction, which implies that additional energy is required from the environment to dry the product (Nkolo Meze'e et al., 2008). This trend is expected, because the desorption process is not spontaneous.

Table 4 lists the centesimal composition and calorific values of pequi mesocarp, dried at different temperatures.
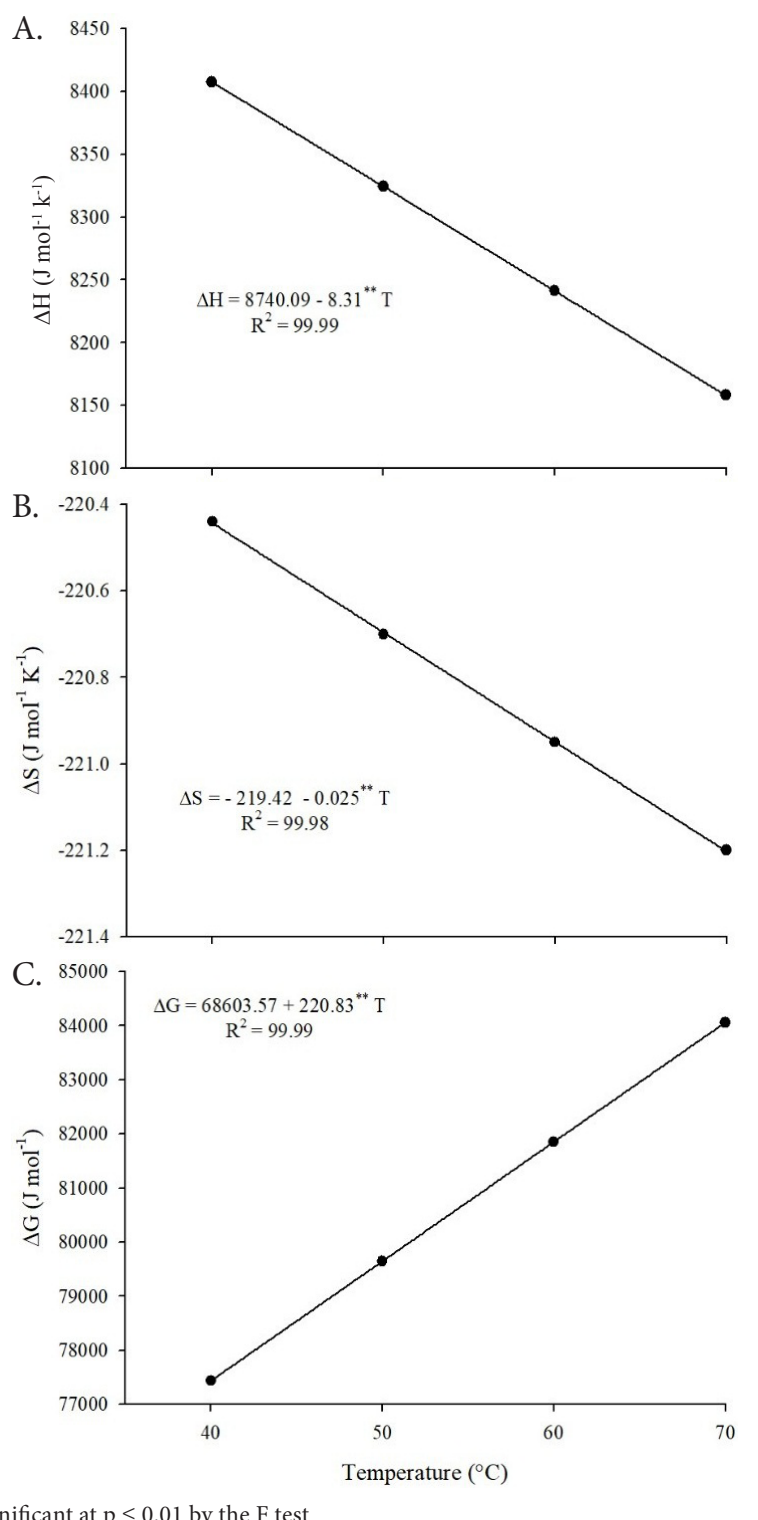

"*- Significant at $\mathrm{p} \leq 0.01$ by the $\mathrm{F}$ test

Figure 2. (A) Enthalpy $(\Delta \mathrm{H})$, (B) entropy $(\Delta S)$ and (C) free Gibbs energy $(\Delta \mathrm{G})$ of pequi mesocarp as a function of drying temperature

The moisture content of the flour products obtained by drying at different temperatures was within the maximum

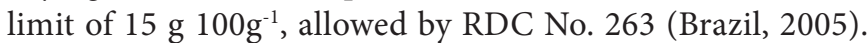
The moisture content was similar to that reported by Pessoa et

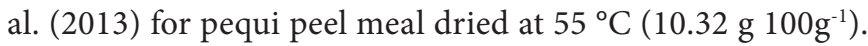
In this study, drying at $40{ }^{\circ} \mathrm{C}$ presented the highest moisture content. The ash content did not vary among the treatments and

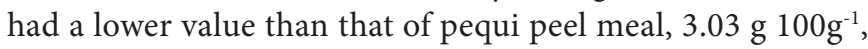
attributed to the presence of the epicarp (Lima et al., 2012).

A low content of ethereal extract was found, on average

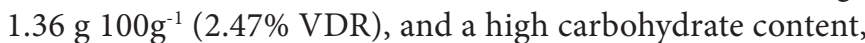

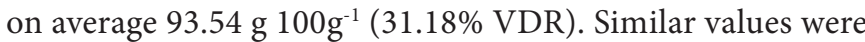
found by Siqueira et al. (2013) with pequi mesocarp dried at $60^{\circ} \mathrm{C}$ :

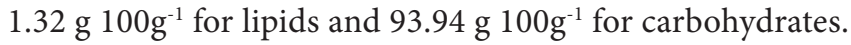

The total energy value did not vary among temperatures

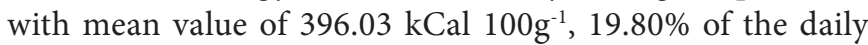
requirement for a healthy adult, demonstrating the importance of this energy source for the communities that make use of it.

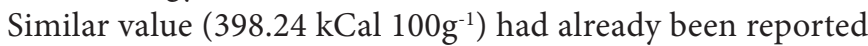
for this product (Siqueira et al., 2013). 
Table 4. Centesimal composition of pequi mesocarp as a function of drying temperature

\begin{tabular}{|c|c|c|c|c|c|}
\hline \multirow{2}{*}{ Variables $\left(\mathrm{g} 100 \mathrm{~g}^{-1}\right)$} & \multicolumn{4}{|c|}{ Drying temperature $\left({ }^{\circ} \mathrm{C}\right)$ (Mean \pm standard deviation) } & \multirow{2}{*}{$\begin{array}{l}\text { CV } \\
(\%)\end{array}$} \\
\hline & 40 & 50 & 60 & 70 & \\
\hline Moisture content & $14.38 \pm 0.82$ & $11.62 \pm 1.50$ & $11.04 \pm 0.77$ & $11.42 \pm 1.95$ & 11.14 \\
\hline Ash & $2.47 \pm 0.06$ & $2.49 \pm 0.11$ & $2.40 \pm 0.25$ & $2.46 \pm 0.15$ & 6.48 \\
\hline Ethereal extract & $1.28 \pm 0.05$ & $1.24 \pm 0.20$ & $1.60 \pm 0.26$ & $1.30 \pm 0.24$ & 15.11 \\
\hline Carbohydrate & $93.41 \pm 0.39$ & $93.49 \pm 0.31$ & $93.15 \pm 0.45$ & $94.10 \pm 0.37$ & 0.41 \\
\hline Energetic value $\left(\mathrm{kCal} 100 \mathrm{~g}^{-1}\right)$ & $395.52 \pm 0.22$ & $395.23 \pm 1.29$ & $397.41 \pm 0.98$ & $395.95 \pm 0.69$ & 0.22 \\
\hline
\end{tabular}

$\mathrm{CV}$ - Coefficient of variation

In Figure 3 the protein values of pequi mesocarp are shown, dried at different temperatures. The pequi mesocarp meal dried at $70^{\circ} \mathrm{C}$ presented a lower protein content compared with the meal obtained by drying up to $60^{\circ} \mathrm{C}$, possibly owing to the denaturation and complexation of amino acids with other compounds, such as carbohydrates, in the Maillard reaction (Moser et al., 1992).

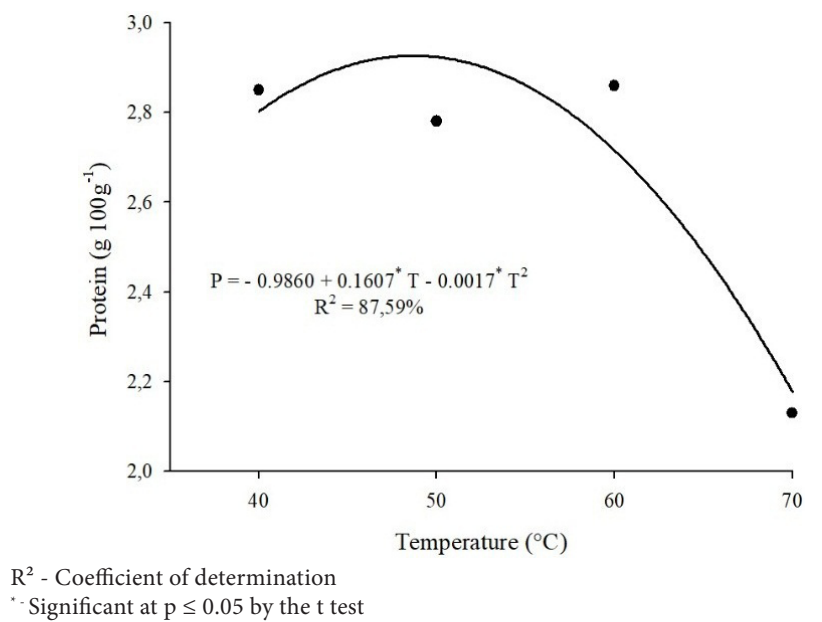

Figure 3. Protein as function of pequi mesocarp drying air temperature

\section{Conclusions}

1. The Midilli mathematical model is recommended to represent pequi mesocarp drying in the temperature range between 40 and $70{ }^{\circ} \mathrm{C}$.

2. The increase in the temperature $\left(40\right.$ to $\left.70{ }^{\circ} \mathrm{C}\right)$ increases the effective diffusion coefficient, reduces the enthalpy of activation and increases entropy (in modulus) and free Gibbs activation energy, as well as decreases the drying time.

3. Temperatures up to $60{ }^{\circ} \mathrm{C}$ do not affect the protein concentration of the mesocarp meal obtained after the drying process and maintain the nutritional quality of the product.

\section{ACKNOWLedgements}

The authors would like to thank Coordenação de Aperfeiçoamento de Pessoal de Nível Superior (CAPES, Brazil), Conselho Nacional de Desenvolvimento Científico e Tecnológico (CNPq, Brazil), Fundação de Amparo à Pesquisa do Estado de Goiás (FAPEG), Financiadora de Estudos e Projetos e Fundação de Apoio à Pesquisa.

\section{Literature Cited}

AOAC - Association of Official Analytical Chemists. Official methods of analysis of the Association of Official Analytical Chemists. 19.ed. Washington: AOAC, 2012.771p.
Bazyma, L. A.; Guskov, V. P.; Basteev, A. V.; Lyashenko, A. M.; Lyakhno, V.; Kutovoy, V. A. The investigation of low temperature vacuum drying processes of agricultural materials. Journal of Food Engineering, v.74, p.410-415, 2006. https://doi. org/10.1016/j.jfoodeng.2005.03.030

Brasil. Resolução RDC n 263, de 22 de setembro de 2005 - Aprova o regulamento técnico para produtos de cereais, amidos, farinhas e farelos. Brasília: ANVISA, 2005. 6p.

Brooker, D. B.; Bakker-Arkema, F. W.; Hall, C. W. Drying and storage of grains and oilseeds. New York: Van Nostrand Reinhold, 1992. 450p.

Goneli, A. L. D.; Correa, P.; Oliveira, G. H. H. de; Botelho, F. M. Water desorption and thermodynamic properties of okra seeds. Transactions of the American Society of Agricultural and Biological Engineers, v.53, p.191-197, 2010. https://doi. org/10.13031/2013.29486

Horwitz, W.; Latimer, G. Official methods of analysis of AOAC International. 18.ed. Gaithersburg: AOAC International, 2005. p.8-36.

Jideani, V. A.; Mpotokwana, S. M. Modeling of water absorption of Botswana bambara varieties using Peleg's equation. Journal of Food Engineering, v.92, p.182-188, 2009. https://doi. org/10.1016/j.jfoodeng.2008.10.040

Kashaninejad, M.; Mortazavi, A.; Safekordi, A.; Tabil, L. G. Thinlayer drying characteristics and modeling of pistachio nuts. Journal of Food Engineering, v.78, p.98-108, 2007. https://doi. org/10.1016/j.jfoodeng.2005.09.007

Kayacier, A.; Singh, R. K. Application of effetive diffusivity approach for the moisture content prediction of tortilla chips during baking. LWT - Food Science and Technology, v.37, p.275-281, 2004. https://doi.org/10.1016/j.lwt.2003.09.003

Khan, M. I. H.; Kumar, C.; Joardder, M. U. H.; Karim, M. A. Determination of appropriate effective diffusivity for different food materials. Drying Technology, v.35, p.335-346, 2016. https://doi.org/10.1080/07373937.2016.1170700

Klink, C. A.; Machado, R. B. Conservation of the Brazilian Cerrado. Conservation Biology, v.19, p.707-713, 2005. https://doi. org/10.1111/j.1523-1739.2005.00702.x

Kumar, C.; Karim, M. A.; Joardder, M. U. H. Intermittent drying of food products: A critical review. Journal of Food Engineering, v.121, p.48-57, 2014. https://doi.org/10.1016/j. jfoodeng.2013.08.014

Lima, T. R. F.; Faria, T. M.; Cordeiro, D. A.; Castro, A. L. A. Avaliação bromatológica do resíduo de pequi. In: Congresso de Ensino, Pesquisa e Extensão, 9, 2012, Goiânia. Anais... Goiânia: Universidade Federal de Goías, 2012. p.8607-8617.

Madamba, P. S. Thin layer drying models for osmotically pré-dried young coconut. Drying Technology, v.21, p.1759-1780, 2003. https://doi.org/10.1081/DRT-120025507 
Merril, A. L.; Watt, B. K. Energy value of foods: Basis and derivation. Washington: United States Department of Agriculture, 1973. $74 \mathrm{p}$.

Midilli, A.; Kucuk, H.; Yapar, Z. A new model for single-layer drying. Drying Technology, v.20, p.1503-1513, 2002. https://doi. org/10.1081/DRT-120005864

Mohapatra, D.; Rao, P. S. A thin layer drying model of parboiled wheat. Journal of Food Engineering, v.66, p.513-518, 2005. https://doi. org/10.1016/j.jfoodeng.2004.04.023

Moreira, R.; Chenlo, F.; Torres, M. D.; Vallejo, N. Thermodynamic analysis of experimental sorption isotherms of loquat and quince fruits. Journal of Food Engineering, v.88, p.514-521, 2008. https:// doi.org/10.1016/j.jfoodeng.2008.03.011

Moser, L. E.; Peterson, M. A.; Kral, D. M.; Viney, M. C. Post-harvest physiological changes in forage plants. In: Moore, K. J.; Khal, D. M.; Viney, M. K. Post-harvest physiology and preservation of forages: Proceedings of a symposium sponsored by C- 6 of the Crop Science Society of America. Madison: Crop Science Society of America Inc., 1992. Chap.1, p.1-20.

Nkolo Meze'e, Y. N.; Ngamveng, J. N.; Bardet, S. Effect of enthalpyentropy compensation during sorption of water vapour in tropical woods: The case of bubinga (Guibourtia tessmanii J. L'Eonard; G. pellegriniana J. L.). Thermochimica Acta, v.468, p.1-5, 2008. https://doi.org/10.1016/j.tca.2007.11.002

Oliveira, G. H. H. de; Corrêa, P. C.; Araújo, E. F.; Valente, D. S. M.; Botelho, F. M. Desorption isotherms and thermodynamic properties of sweet corn cultivars (Zea mays L.). International Journal of Food Science \& Technology, v.45, p.546-554, 2010. https://doi.org/10.1111/j.1365-2621.2009.02163.x
Park, K. J.; Yado, M. K. M.; Brod, F. P. R. Estudo de secagem de pêra Bartlett (Pyrus sp.) em fatias. Ciência e Tecnologia de Alimentos, v.21, p.288-292, 2001. https://doi.org/10.1590/S010120612001000300007

Pessoa, M. S.; Avelar, J. C. S.; Nascimento, A. L. H.; Silva, K. L; Soares, A. C. M.; Camargo, A. C. S.; Faria Filho, D. E. Performance of Nile tilapia fed with bran made of pequi peel. Arquivo Brasileiro de Medicina Veterinária e Zootecnia, v.65, p.547-552, 2013. https:// doi.org/10.1590/S0102-09352013000200034

Silva, R. M.; Placido, G. R.; Oliveira, D. E. C.; Silva, M. A. P.; Caliari, M. Pequi pulp (Carypocar brasiliense Cambess): Drying kinetics and thermodynamic properties. African Journal of Biotechnology, v.13, p.3443-3449, 2014. https://doi.org/10.5897/AJB2014.13944

Siqueira, B. S. dos; Soares Júnior, M. S.; Fernandes, K. F.; Caliari, M.; Damiani, C. Effect of soaking on the nutritional quality of pequi (Caryocar brasiliense Camb.) peel flour. Food Science and Technology, v.33, p.500-506, 2013. https://doi.org/10.1590/S010120612013005000081

Sousa, E. P. de; Figueirêdo, R. M. F. de; Gomes, J. P.; Queiroz, A. J. de M.; Castro, D. de S.; Lemos, D. M. Mathematical modeling of pequi pulp drying and effective diffusivity determination. Revista Brasileira de Engenharia Agrícola e Ambiental, v.21, p.493-498, 2017. https://doi.org/10.1590/1807-1929/agriambi.v21n7p493-498 Strumillo, C.; Kudra, T. Drying: Principies, aplications and design. New York: Gordon and Breach Science Publisher, 1986. 448p.

Vera, R.; Naves, R. V.; Nascimento, J. L. do; Chaves, L. J.; Leandro, W. M.; Souza, E. R. B. de. Caracterização física de frutos do pequizeiro (Caryocar brasiliense Camb.) no Estado de Goiás. Pesquisa Agropecuária Tropical, v.35, p.71-79, 2005. 